\title{
The Reduction of Interest among Elementary Students in the Field of Technical Education
}

\author{
$\underline{\text { http://dx.doi.org/ijep.v1i3.1822 }}$ \\ I. Handlovská, T. Kozík \\ Univerzita Konštantína Filozofa, Nitra, Slovakia
}

\begin{abstract}
There are several factors that bring down student interest in technical education within Slovakia and other European Union countries. Authors of this article have now considered one effective method that could improve this situation. This new method is to change of teaching strategies by applying methods of creative thinking. The article further examines the demonstration of these methods applied in elementary schools and defines barriers to their application in educational practice.
\end{abstract}

Index Terms - changes in technical education, creativity, development, interest, skills, strategy, technical education.

\section{INTRODUCTION}

We now live in the 21 st century and this is a time of significant technological breakthroughs, however, for several years we have observed a trend of reducing interest in technical education within all elementary school graduates within the European Union. These graduates tend to not continue their studies at secondary vocational schools with a technical focus. Teachers are now showing students a video on how a certain project is completed instead of showing the students how to create the project with a hands on activity. This is one of the many reasons children are beginning to loose complete interest in technical education. This problem can be resolved by improving conditions and teaching strategies in EU countries.

\section{II. The Reasons Why Technical Education Might Not Be As Popular IN ElEMENTARY SCHOOLS}

Today it is very typical to see, not only in Slovakia, that students are taught too much information and they are forced to memorize it word for word. This approach to teaching technical education has not ever been effective and never will be because students' ideas have been suppressed. Students do not have space for their own creativity, and the danger here is that they will never be able to solve any problems at work or school. We support the idea, "if teachers of technical education keep it very informative and focus on theory, the technical education will keep its educative face.", however it will not help to increase the interest of elementary school students because of loading them with information and not giving them any space for their own creativity.

The authors see a solution in building a new curriculum that will dedicate parts to fun activities and interesting strategies in order to encourage students' decision making.

It is essential for teachers to be supported by their supervisors and parents when promoting the progressive strategies into the educative process. If that will not come to practice, then there is a possibility that teachers of tech- nical education will not feel any satisfaction. They will also feel underestimated and will not want to change their strategies. These teachers search for more available information related to their subject during their free time which is not perspective to the quality of education.

Technical education teachers in Slovakia feel an absence of needed textbook materials as well as technology tools and classrooms [2]-[3]. Surveys done within the last few years have shown that manual practice has been neglected.

Students shall train the skills acquired in technical education class in their every day lives, which will influence their personal value hierarchy [4].

\section{III. TECHNICAL SKILLS OF TODAY’S YOUTH}

The next reason why the interest in technology education has dropped is because of students' lifestyles and hobbies. Parents, psychologists and education workers can see a change in behaviour when they compare the current youth with the youth from the past. Students and children have more options on how to gain knowledge today than their parents did. The digital era of today's society offers a more comfortable and fast access to all the information.

The situation of technical education in elementary schools is not inspiring. OECD PISA 2009[5], a study done among 15 year old children showed a decline in interest. So what is influencing these teenage children in their lives? We looked into a book called Dumbest generation (Bauerlein). The author of this book states that, "The technology that was supposed to make young adults more astute, diversify their tastes, and improve their minds has had the opposite effect." [6]

Although Baurelein describes only young Americans in his book, it is happening all over the world to the youth in every country. Despite the fact that all Americans are growing up in an environment that is allowing them a better access to all the information such as, huge libraries, various fun activities and especially easy access to scientific information, they are not smarter than their ancestors.

Young people use networking not to gain knowledge but to connect with one another. The original idea was to share and offer more ways to get to free information, which as once the sae in the past but now has been abused by the youth - they find technology very entertaining and misuse it just to have fun, satisfying their own needs rather than intellectual growth.

"Thirst for knowledge should be met as well as yearning for fun" [6], this statement insinuates that all teachers should try to merge technical education with fun. Educators realize that children are influenced best through their leisure time activities. The goal here is make the tech- 
PAPER

nologies support them in their efforts. In Slovakia it is now common to see computers in classrooms with internet capabilities. Teachers use videos, simulations and other digital products which their students love to work with because they are familiar with the internet and get to use it at home as well as in school.

Although the educators realize all the pros of the electronic teaching aids, they need to learn about the cons. Teaching Technical Education workshops by solely using the internet as the main source and not combining it with the hands on training is not meeting the goal of the class [7] [8]. If not met, there is nothing to help children develop their skills and work habits. It does not form a need of finishing a started project, or thoroughly follow the instructions, or the correct use of the tools used in the classroom. Simulation will never replace the real work, will never spread the smell of the wood or other materials and will never train hand power and correct pressure. Despite all of these named things, teachers are still attracted to use computers, programs and simulations.

M. Bauerlein's book ignited many discussions in professional circles. Authors of this article think that this book is a warning to all of the teachers who wish to make their classes more appealing, exclusively through digital technologies. It is obvious that the school system and its curriculum in elementary schools need several changes if we want to make classes more attractive to students. The quality of educating any subject directly depends on the quality of standards. According to the "Standards for Technological Literacy [9], they should be developed accordingly to the students age. Theory and hands on training should follow up material studied in the class from the previous level and extend the contents gradually. Since parents play an important role in the educative process of their children (main role model for children of secondary schools) as well as teachers of any type of school level, engineers, biologists and mathematicians, they all should take part in creating education standards.

\section{IV. INCREASING INTEREST IN TECHNICAL EDUCATION STRATEGY}

In the previous part of the article, we mapped out some reasons that have obvious influence on decrement of pupils' interest in technical education from the point of view of a teacher. To realize changes that would lead to the change of pupils' attitude towards technical education, it is needed to form an unambiguous answer to the question, "What can we do to improve the situation?" under contemporary educational conditions.

When judging the current state of technical education, we have decided to orientate our attention to the area of effectiveness of education. We agree that students should not only get knowledge in schools but also other precious values like morality, positive attitudes towards society, vocational skills and competencies. The interest is not an inborn human attribute, it is possible to develop it.

That leads us to conclusion that teacher's fundamental interest should lie in the forming of the pupils' interest in the subject content, in a way so that pupils may acquire positive attitude towards the subject itself. Through this attitude they may also develop their other interests. One of the ways to encourage them is the approximation of the subject content towards pupils' experience. Everything that teachers offer to his pupils, should be connected with their experiences and skills.

Every teacher should emphasize meaning of the lesson content. They need to deploy means and methods that support this educational experience. If we want to develop pupils creative thinking, we have to start involving them into the educational process. Justified methods of this process are those which allow the initiation of creative ideas from pupils and they even offer the possibility of obtaining theoretical knowledge and its deeper understanding in entertaining form. According to Turek in the monograph Didactics, methodical development of creative thinking may be considered as so called activating methods in education. They develop individual attributes and naturally extend areas of interests among all pupils, not only the best ones. According to Gardner (2005) suggestive methods represent great motivational elements in education.

Unfortunately, these strategies in education are often ignored by teachers, though they might be of great importance in pupils' comprehension of scientific knowledge in the context.

Their application of this process creates brand new neural connections in the brain, this supports their creativity and helps to develop intelligence.

Methods for development of creative thinking greatly stimulate communication, cooperation and they teach pupils how to use obtained knowledge. Such education offers more space for using one's own opinions and ideas. Other positives are readiness of pupils to solve tasks, originality in their thinking and stimulation of curiosity. Development of technical creativity at lower level elementary schools may be one of the ways to strengthen interest of pupils in further technical education and later in work in technical sphere.

\section{A. Technical Creativity}

Creativity of pupils may be trained and developed in various different ways. Recently, the emphasis is being put on programs that allow and support creative thinking. Research outcomes in [13]-[14] show that not every school subject offers ideal space for development of creative thinking. A group of technical subjects allow teachers to stimulate new ideas among pupils to lead them towards independent creative thinking via these activities: design of technical solution, construction creation and many other interesting activities. The key outcomes in this area are products in both material and non-material form (image, idea, new strategy of thinking, positive change in thinking style). The term "creative performance of pupils in technical education" may be represented by small improvement suggestions, small gadget corrections via improvisation, usage of old equipments in a new way or practical deployment of everyday items in a different and unusual way [15]. Presently, application and realization of programs dealing with development of creativity in technical subjects is on a minimal level. The research mentioned in [16] showed low percentage in use other than traditional approaches in teaching technology at elementary schools. 112 respondents (teachers of technology at elementary schools) confirmed a low ratio of used creative strategies in the educational process. There is an obvious lack of game activities, real simulations, problem and project teaching. Discussion as a means of support of pupils' creativity seems to be the most frequent educa- 
tional approach. Technical Olympic games or technical creative workshops are organized once a year. All abovementioned activities have temporary positive influence on pupils and students, but from a long term point of view their influence seems to be irrelevant.

\section{V. Weaknesses of Usage of Strategies Dealing WITH DEVELOPMENT OF PUPILS' CREATIVITY}

From the position of a teacher we can easily imagine that the change of teaching strategies is not an easy process. If we want to change the thinking of pupils, it is necessary to change the curriculum (educational content). Using an educational model in teaching Technology does not automatically change the way of perception, thinking or evaluation of pupils. It is needed to change the set of pertinent items like textbooks, practice sheets and the material-technical facilities. The lack of technical lessons per week also represents one crucial obstacle.

It is important to realize that if we do not create sufficient space for development of individual creative thinking at the level of elementary school, it is probable that we may waste the most suitable time in the process of forming creative human personalites. Some crucial psychical changes occur in the course of development of young people that leads to constraints in production of creative ideas. From the developmental point of view it is recommended to intensively stimulate creativity already at the level of pre-primary education.

Entry into elementary school is usually accompanied with the first decrement in creative activity [17]. More research projects [18] orientated on the development of creativity realized in conditions of Slovak elementary schools show that there is an obvious decrement in creativity between the 6th and 8th year of students' lives and following growth begins between the 10th and 11th year. Here it is recommended to practice so called creativity supporting interventions. Later there comes the age of defending strategies [12-13y.] with characteristic radical decrement in ability to think creatively. After this period, creativity gradually grows and becomes more stable. Good teachers should always take into consideration particular developmental abilities of children when choosing teaching strategies. Success of the development of creative abilities in children is contingent on developmental changes, still there are many obstacles remaining:

- Small cohesion between curriculum, recommendations and demands of practice. Minimal application of recommendations in connection to implementation of creativity into educational process (with the exception of alternative schools and classes for gifted students).

- non-equal deployment of methods supporting creativity in the frame of primary and lower secondary level at elementary schools. More attention is paid to development of creative thinking of pupils at primary level via methods of games and competitions.

- Schools which realize various programmes supporting creativity do not receive sufficient funds from the state budget, or they are mostly orientated on gifted students

- Teachers are not fully ready to use strategies supporting creativity of pupils. There are qualified teachers missing at elementary schools who would teach the subject Technology, majority of teachers is a group of elder ones who usually do not master innovative or non traditional approaches of teaching based on discussion and support of pupils' ideas

- Serious deficiencies are seen even in the preparation of future teachers. Only a few teaching study programmes include subjects where students (future teachers) would have a chance to develop their own creative abilities and to get ready for development of creativity among their pupils in the future.

Even in the vocational community, there is a voice expressing an idea about non sufficient support of creative approaches in education at high schools and universities.

It is generally said that the application of creative ideas at the level of higher education is not as frequently used as it should be. Only 2 per cent of tasks and questions that are addressed towards students in the course of the university study are orientated on creative - divergent thinking (research realized at Slovak high schools and universities). During their studies students attend many vocational lectures, they have no problem to access scientific findings from the area of particular study branch, they can easily gain information on various techniques supporting creative thinking, as in [19], but unfortunately not all study programmes offer direct training or specialized seminars on creative solutions in the selected subject.

The ability of creative thinking can be profound and strengthened via solutions of technical tasks and issues that lead pupils towards independence and self-reliance. Often we witness situations in the educational process where there is a flagrant absence of creative approaches. Before entering school many children have developed as independent creative beings, and suddenly facing a new school environment, they are influenced by teachers who usually demand only memorized answers without an emphasis on the individual personality of a child.

An apposite and still valid idea of an American creatologist Ken Robinson: "School teaches children to obey and not to be mistaken, but when we are not ready to be mistaken we can never find out anything original. We do not grow into creativity, but get away from it; contemporary education divides us from the very principle of creativity." [20] School environment and personality of teachers have the power to influence creative thinking in pupils in either negative or positive ways.

\section{VI. What Are We About to Face When Ignoring NEEDED CHANGES IN TECHNICAL EDUCATION?}

The low rate of interest in technical education at elementary schools directly influences pupils' interest in further study of technical branches at secondary schools and universities. Unless we see social appreciation and support of technical education, it will gradually decline and vanish at the level of elementary school and what seems to be much worse, interest of aspirants to technical branches shall not be sufficient. Often we hear opinions that the content of technical education may be easily and almost naturally provided in the frame of some different subjects like Physics, Mathematics or Computer Science; nevertheless, we dare express serious doubts on correctness of this idea.

This era of information society brings and creates other dangers - it is benevolence in choice of hobbies and free 
time activities of young people. Thanks to modernization of technical education, supported by Information Communication Technologies, we expect further intellectual decline of children and youth in the future. In future years, a new generation without any manual skills may substitute us!

If we keep the system of just teaching bare facts, our schools shall change into factories, where the main goal of education would lie in providing information without real and pure interest in the forming of pupils and preparing them for their future. Students will not be ready for practice nor able to think critically and independently. Schools remain labelled as institutions oppressing creativity of their own students. As a warning may serve this recommendation [21]; let the parents themselves develop creativity of their children.

\section{VII. CONCLUSION}

Recommendations of the European Parliament and the Council of Europe on key competencies [22] that every member of the society should gain and develop in the frame of lifelong education, emphasize the creative competence that may be obtained by application of innovative forms of education. The ability to creatively solve problems is inevitable for life and practice. All human beings have a potential to display creativity from the very beginning and this attribute guides them in the course of all their lives. Every progressive educational system should be conceived to create space for improvement of the individuals in the area of technical creativity and forming of personal interests throughout the process of school education. To learn how to create is not an easy task. Training of creative thinking is a long-term process that requires suggestive environments and professional approaches. Deployment of creative elements in technical education is the way that to allow pupils' interest to increase in the study of technical subjects and branches.

\section{REFERENCES}

[1] Turek, I. 2011. „Globalizácia a jej vplyv na inováciu technického vzdelávania."s. 8-12 [online] 27.jún 2011. <http://www.pulib.sk/ elpub2/FHPV/Pavelka1/19.pdf>.

[2] Kozík, T. 2005. Východiská technického vzdelávania v krajinách EU. S. 110-125. In Zborník z vedeckého semináru Kultúra komunikácie v informačnej spoločnosti. Vydal AK UKF 2005. ISBN: 80-8050-872-0.

[3] Bánesz, G. - Lukáčová, D. - Sitáš, J. 2010. Technické vzdelávanie v digitálnom prostredí. PF UKF Nitra. 104 s. ISBN 978-80-8094713-2.

[4] Kurincová, V. In Handlovská, I. 2011. „Návrh vyučovacej hodiny na tému práca s drevom pre školy bez dielní." In Zborník z doktorandskej konferencie. UKF Nitra (v tlači).

[5] OECD PISA 2009, Národná správa Slovensko, [online] 19.5.2011 Dostupné na internete s.44-57<http://www.nucem.sk/documents/ 27/medzinarodne merania/pisa/publikacie/Narodna sprava Slove nsko_PISA_2009.pdf>.

[6] Bauerlein, M. 2010. DumbestGenaration. Preklad: Najhlúpejšia generácia. Ako digitálna éra ohlupuje mladých Američanov a ohrozuje našu budúcnost' alebo: Never nikomu pod 30. Spolok slovenských spisovatel'ov, preložené 2010. S. 194. ISBN 978-808061-431-7.
[7] Handlovská, I., Garláty, V. 2011. ALTERNATIVE APPROACHES FOR TECHNICAL EDUCATION IN SLOVAK ELEMENTARY SCHOOLS. In Zborník z InternationalScientificElectronicConferenceFor PHD Students, Researchers and YoungUniversityTeachers, Prešov 20.6.2011. [online] Dostupné na internete: <http://konferenciapresov2011.weebly.com/10/post/ 2011/06/handlovsk-ivica-garlty-viliam-alternatvne-prstupy-vovyuovan-techniky-v-podmienkach-slovenskch-zkladnch-kl.html $>$.

[8] Krušpán, I. 1989. Didaktika odborného výcviku. VŠLD Zvolen, 1989. 118 s. ISBN 80-85162-03-2.

[9] Vaňková, H. - Vaněk, V.: Standardy pro vseobecné technické vzdelání americká zkušenost. [online] 22.11.2005. Dostupné na internete: <http://clanky.rvp.cz/clanek/o/z/402/STANDARDYPRO-VSEOBECNE-TECHNICKE-VZDELAVANI--AMERICKA-ZKUSENOST.html/>.

[10] Hoang, Thienhuong 2007. Creativity: A Motivational Tool for Interest and Conceptual Understanding in Science Education. [online] 2.8.2007 Dostupné na internete: $<$ http://www.waset.org/ journals/ijhss/v2/v2-8-80.pdf $>$.

[11] Turek, I. 2008. Didaktika. IuraEdition, BA: 2008, prvé vydanie. 595.s. ISBN 978-80-8078-198-9.

[12] Gardner, H. 2005 Intelligence Reframed. New York: Basic Books In Hoang, Thienhuong 2007. Creativity: A Motivational Tool for Interest and Conceptual Understanding in ScienceEducation. [online] 2.8. $2007<$ http://www.waset.org/journals/ijhss/v2/v2-880.pdf>.

[13] Tóthová, M. 2006. Rozvoj tvorivosti na prvom stupni ZŠ. PF UKF v Nitre, 2006. 196 s. ISBN 80-8094-033-9.

[14] Jurčová, M. 2009. Tvorivost' v každodennom živote a vo výskume. Iris 2009. ISBN 978-80-89256-42-6. s. 32 - 33.

[15] Krušpán, I. 1989. Didaktika odborného výcviku. VŠLD Zvolen, 1989. $118 \mathrm{~s}$. ISBN 80-85162-03-2.

[16] Handlovská, I. 2010 (prieskum foriem technického vyučovania na ZŠ v školskom roku 2009/2010 doposial' nepublikované údaje).

[17] Hlavsa, In Krušpán, I. 1989. Didaktika odborného výcviku. VŠLD Zvolen, 1989. s.85. ISBN 80-85162-03-2.

[18] Lokšová, I.- Lokša, J. 1999. Pozornost, motivace, relaxace a tvořivostdětí vo škole. Portál, Praha 1999.199 s. ISBN 80- 7178205-X.

[19] Fichnová, K.: Tvorivá komunikácia a rozvoj tvorivého potenciálu u vysokoškolákov študentov masmediálnych štúdíi. [online] str.1 Dostupné na internete: <http://www.fem.uniag.sk/uveu2005/ zbornik/zbornik/sekcia 1/fichnova.pdf $>$.

[20] Robinson, K. 2006. Schools kill creativity. [online] 2010 [cit. jún 2006]. Dostupné na internete: <http://www.ted.com/talks/lang/ slo/ken_robinson_says_schools_kill_creativity.html $>$.

[21] Bean, R. 1992. How to Develop Your Children's Creativity, Price Stern Sloan. Los Angeles, California. Preklad České vydanie Portál, Praha, 1995. ISBN 80-7178-035-9.

[22] Rozhodnutie Európskeho parlamentu a Rady Európy o Európskom roku tvorivosti a inovácie [online] (2009) Dostupné na internete: $<$ http://www.modernaskola.sk/directories/file-upload/tvorivostinovacia/Rozhodnutie ERTI2009.pdf>.

\section{AUTHORS}

T. Kozik is with Constantine The Philosopher University in Nitra, Faculty of Education, Slovakia. He is the Deparment Chairman of Technical Education. (e-mail: tkozik@ukf.sk).

I. Handlovská is with Constantine The Philosopher University in Nitra, Faculty of Education, Slovakia. She is a PhD candidate. (e-mail: ivica.handlovska@ukf.sk).

Received 22 September 2011. Published as resubmitted by the authors 30 September 2011. 